\title{
Influence of controlled breeding techniques on fertility and plasma progesterone, protein and cholesterol profile in true anestrus and repeat breeding buffaloes
}

\author{
K. K. Savalia ${ }^{1}$, A. J. Dhami ${ }^{1}$, K. K. Hadiya ${ }^{1}$, K. R. Patel ${ }^{1}$ and N. P. Sarvaiya ${ }^{2}$
}

1. Department of Animal Reproduction, Gynaecology and Obstetrics, College of Veterinary Science and Animal Husbandry, Anand Agricultural University, Gujarat, India; 2. Reproductive Biology Research Unit, College of Veterinary Science and Animal Husbandry, Anand Agricultural University, Gujarat, India.

Corresponding author: A. J. Dhami, e-mail: ajdhami@aau.in, KKS: ketan89862@gmail.com, KKH: kamleshhadiya@yahoo.co.in, KRP: ketanfriend007@gmail.com, NPS: npsarvaiya@aau.in

Received: 13-05-2014, Revised: 05-08-2014, Accepted: 11-08-2014, Published online: 27-09-2014

doi: 10.14202/vetworld.2014.727-732. How to cite this article: Savalia KK, Dhami AJ, Hadiya KK, Patel KR, Sarvaiya NP (2014) Influence of controlled breeding techniques on fertility and plasma progesterone, protein and cholesterol profile in true anestrus and repeat breeding buffaloes, Veterinary World 7(9): 727-732.

\begin{abstract}
Aim: The aim was to evaluate the estrus response, conception rate and plasma profile of progesterone, protein and cholesterol following use of different hormonal protocols in anestrus and repeat breeding buffaloes.

Materials and Methods: This study was carried out on 20 true anestrus, 20 repeat breeders, and 10 normal cyclic buffaloes. Ten anestrus buffaloes each were treated with standard controlled internal drug releasing (CIDR) i/vg device and Ovsynch (GPG) protocols with fix timed artificial insemination (FTAI), and blood samples were obtained on day $0,7,9 / 10$ (AI) of treatment and day 21 post-AI. Ten repeat breeding buffaloes with mature mid-cycle palpable corpus luteum (CL) were treated with $\mathrm{i} / \mathrm{m}$ injection of $25 \mathrm{mg}$ prostaglandin $\mathrm{F} 2 \alpha\left(\mathrm{PGF}_{2} \alpha\right)$ with FTAI twice at 72 and $96 \mathrm{~h}$ later, whereas other ten repeat breeding buffaloes in standing estrus were inseminated with simultaneous $\mathrm{i} / \mathrm{m}$ injection of buserelin acetate-gonadotropinreleasing hormone $(\mathrm{GnRH}) 20 \mu \mathrm{g}$. 10 buffaloes exhibiting first estrus within 90 days postpartum and inseminated without any treatment served as normal cyclic control. Blood samples were obtained on day of PG injection, day of AI and day 21 post-AI for estimation of plasma progesterone, protein, and cholesterol.
\end{abstract}

Results: CIDR and Ovsynch protocols resulted in 100 and $80 \%$ induction of estrus with conception rates of 40 and $30 \%$ at induced estrus, respectively, in anestrus buffaloes. Mid-cycle $\mathrm{PGF}_{2} \alpha$ treatment resulted in $90 \%$ estrus induction and $40 \%$ conception rate at induced estrus, while Buserelin acetate-GnRH $20 \mu \mathrm{g}$ injection at AI resulted in 30\% conception rate in repeat breeders. In normal cyclic control group also, the first service conception rate was $30 \%$. The mean plasma progesterone concentrations on day $0,7,9 / 10(\mathrm{AI})$ of treatment and on day 21 post-AI were found to be significantly $(\mathrm{p}<0.05)$ different in both CIDR and Ovsynch protocols, being higher on day 7 (day of PG injection) and on day 21 post-AI than on day 0 and $9 / 10$ (FTAI), which were near basal levels. The mean plasma progesterone level was significantly $(\mathrm{p}<0.01)$ higher on the day of initiation of mid-cycle $\mathrm{PGF}_{2} \alpha$ treatment $(3.81 \pm 0.67 \mathrm{ng} / \mathrm{ml})$ in a repeat breeding buffaloes suggesting luteal phase. The mean plasma $\mathrm{P}_{4}$ levels on day 21 post-AI were significantly $(\mathrm{p}<0.01)$ higher than on the day of estrus in both repeat breeders and in normal cyclic controls. The plasma $\mathrm{P}_{4}$ value on day 21 post-AI was significantly $(\mathrm{p}<0.01)$ higher in conceived than non-conceived buffaloes in all five groups. The mean plasma total cholesterol and total protein concentrations in anestrus and repeat breeding buffaloes under different treatments did not vary significantly between sampling days. However the cholesterol content was significantly $(\mathrm{p}<0.05)$ lower $(79.96 \pm 2.17 \mathrm{vs} .92 .27 \pm 6.04 \mathrm{mg} / \mathrm{dl})$ and protein higher $(8.14 \pm 0.73 \mathrm{vs}$. $7.69 \pm 0.59 \mathrm{~g} / \mathrm{dl})$ in conceived than non-conceived animals. In both anestrus and repeat breeding buffaloes, the values of cholesterol and protein were significantly lower than in normal cyclic control group $(138.04 \pm 11.98 \mathrm{mg} / \mathrm{dl}$ and $7.82 \pm 0.11 \mathrm{~g} / \mathrm{dl}$, respectively).

Conclusion: The results showed that CIDR was better than Ovsynch protocol in inducing fertile estrus in anestrus buffaloes, while mid-cycle PG treatment was superior over AI + GnRH in repeat breeders, and all four treatment protocols significantly influenced plasma P4 profile, but not the protein or cholesterol.

Keywords: anestrus, biochemical profile, buffalo, conception rates, plasma progesterone, repeat breeder, synchronization protocols.

\section{Introduction}

The buffaloes are regarded as the backbone of the dairy industry in India. The maintenance of optimum calving interval of 13-14 months is desirable in them, and it depends upon the buffaloes' ability to conceive within 90 and 120 days of calving.

Copyright: The authors. This article is an open access article licensed under the terms of the Creative Commons Attributin License (http:// creative commons.org/licenses/by/2.0) which permits unrestricted use, distribution and reproduction in any medium, provided the work is properly cited.
Unfortunately, this seldom occurs under field conditions. Low reproductive efficiency and problems of subestrus, anestrus, repeat breeding are major constraints in buffalo breeding. It is, therefore, inevitable to use certain hormonal protocols like controlled internal drug releasing (CIDR), Ovsynch, Cosynch etc. to induce and synchronize estrus with fix timed artificial insemination (FTAI) in anestrus/subestrus animals [1-4]. Similarly, inducing mid-cycle luteolysis using prostaglandins (PGs) with fix timed 
insemination 72 and $96 \mathrm{~h}$ later, and/or administering Gonadotropin-releasing hormone (GnRH)/human chorionic gonadotropin hormone simultaneous to AI at spontaneous estrus in repeat breeding cows and buffaloes have been found to improve conception rate [5-7]. The present study was therefore aimed to evaluate the estrus induction and fertility response, and whether the serum progesterone, protein and cholesterol profile could be altered by using CIDR and Ovsynch protocols in true anestrus buffaloes, and mid-cycle $\mathrm{PGF}_{2} \alpha$ and $\mathrm{AI}+\mathrm{GnRH}$ regimes in repeat breeding buffaloes.

\section{Materials and Methods}

\section{Ethical approval}

The prior approval from the Institutional Animal Ethics Committee was obtained for use of farmers animals in this study.

\section{Selection of animals}

This study was carried out during breeding season (year 2012-2013) on 50 pluriparous $90-180$ days postpartum buffaloes of average BCS. These comprised 20 true anestrus, 20 repeat breeding and 10 normal cyclic (control) buffaloes selected from five villages under the milk shed area of AMUL, Anand, Gujarat. The buffaloes were initially screened gyneco-clinically for their reproductive status. Buffaloes having both ovaries small smooth inactive without estrus activity and functional structure on per rectal examination twice 10 days apart were taken as true anestrus ones, while those cycling regularly without any visible or palpable genital abnormalities and inseminated with good quality frozen-thawed semen 3 or more time yet failed to conceive were considered as repeat breeders. The anestrus and repeat breeders were then subjected to different therapeutic regimes with FTAI. Buffaloes in spontaneous or induced estrus were inseminated using good quality frozen-thawed semen. All selected buffaloes were dewormed by administering ivermectin $70 \mathrm{mg} \mathrm{s} / \mathrm{c}$ and fenbendazole $3 \mathrm{~g}$ orally.

\section{Treatment protocols-anestrus}

Twenty true anestrus buffaloes were treated initially once intramuscularly with sodium acid phosphate $2 \mathrm{~g}$ (injection alphos-40, $10 \mathrm{ml}$, pfizer) and multivitamins $\mathrm{AD}_{3} \mathrm{E}$ injection (injection vetacept, $10 \mathrm{ml}$, Concept Pharma). They were then randomly subjected to either standard CIDR or Ovsynch protocol $(n=10$ each) with FTAI on day 9 and 10, respectively, as per Bhoraniya et al. [2], except that estradiol valerate was not used in conjunction with these protocols.

\section{Treatment protocols-repeat breeders}

Twenty repeat breeding buffaloes without visible and palpable genital abnormalities were treated initially once with $\mathrm{i} / \mathrm{m}$ injection of $3.0 \mathrm{~g}$ enrofloxacin (injection conflox, $15 \mathrm{ml}$, concept pharma) to check invisible genital infection, if any. 10 repeat breeding buffaloes with palpable mid-cycle corpus luteum (CL) on the ovary were injected $\mathrm{i} / \mathrm{m}$ with $\mathrm{PGF}_{2} \alpha 25 \mathrm{mg}$ (injection lutalyse, $5 \mathrm{ml}$, pfizer) and FTAI was done twice at 72 and $96 \mathrm{~h}$ later. Other 10 repeat breeding buffaloes with clear standing estrus were inseminated and administered simultaneously with $\mathrm{i} / \mathrm{m}$ injection of GnRH $20 \mu \mathrm{g}$ (injection receptal, $5 \mathrm{ml}$, intervet).

\section{Control group}

Ten buffaloes detected in estrus spontaneously within 90 days postpartum and inseminated using good quality frozen-thawed semen without any treatment served as normal cyclic control. Animals in all the groups once inseminated were followed for recurrence of estrus and in non-return cases pregnancy was confirmed per rectum 60 days post-AI.

\section{Blood sampling}

The jugular blood samples were collected in heparinized vacutainers from true anestrus animals on day 0 (just before treatment), day 7 (at the time of $\mathrm{PGF}_{2} \alpha$ administration), day 9 (CIDR)/10 (Ovsynch), i.e., induced estrus/AI and on day 21 post-AI. Similarly in repeat breeding and normal cyclic buffaloes, blood sampling was done depending upon treatment protocol, i.e., on the day of mid-cycle $\mathrm{PGF}_{2} \alpha$ injection, at the time of spontaneous/induced estrus (AI) and on day 21 post-AI. The samples were centrifuged at $3000 \mathrm{rpm}$ for $15 \mathrm{~min}$, and plasma was stored deep frozen at $-20^{\circ} \mathrm{C}$ with a drop of merthiolate $(0.1 \%)$ until analyzed.

\section{Plasma assay}

Plasma progesterone concentrations were determined by employing standard radio-immuno-assay technique [8]. Labeled antigen $\left(\mathrm{I}^{125}\right)$, antibody coated tubes, and standards were procured from Immunotech, France. The sensitivity of the assay was $0.1 \mathrm{ng} / \mathrm{ml}$. The intra- and inter-assay coefficients of variation were 5.4 and $9.1 \%$, respectively. Plasma total protein and cholesterol levels were estimated using standard procedures and assay kits procured from Crest Bio-systems, Goa, India, with the help of Chemistry Analyzer (Mindray, BS 120, China).

\section{Statistical analysis}

The data on estrus response, conception rate (by Chi-square test) and plasma profile of progesterone, protein, and cholesterol (ANOVA) were analyzed statistically using online SAS software.

\section{Results and Discussion}

\section{Estrus response and fertility}

Out of 10 true anestrus buffaloes each treated with CIDR and Ovsynch protocols, $100 \%$ and $80 \%$ buffaloes responded with expression of behavioral estrus within $63.60 \pm 6.46$ and $70.67 \pm 6.15 \mathrm{~h}$, respectively, from the time of $\mathrm{PGF}_{2} \alpha$ injection, which is in accordance with the earlier observations in anestrus buffaloes and crossbred cows [3,6,9]. Contrary to present findings, much lower estrus induction response of 58.33 and $37.5 \%$ was recorded with CIDR protocol by Ravikumar et al. [4] and Singh et al. [10], respectively. The present finding of $80.00 \%$ estrus response 
obtained with Ovsynch protocol in anestrus buffaloes compared favorably with the earlier report [11] in anestrus buffaloes (87\%), although Naikoo et al. [3] found $100 \%$ estrus response, while Ali et al. [12] found it as $50 \%$ only in anestrus buffaloes. Further, $90 \%$ of repeat breeding buffaloes responded to mid-cycle $\mathrm{PGF}_{2} \alpha$ injection with expression of behavioral estrus within $69.50 \pm 4.50 \mathrm{~h}$. This is also in line with the intervals reported earlier [7,13]. Khasatiya et al. [14], however, observed this interval as $4.07 \pm 0.53$ days in 5 months postpartum subestrus Surti buffaloes.

The conception rates at induced estrus in CIDR and Ovsynch treatment groups were 40 and $30 \%$ and in normal cyclic control group it was $30 \%$, with the overall conception rates of three cycles as 70,60 and $60 \%$, respectively (Figure-1). The conception rates with CIDR protocol were better than Ovsynch protocol and even control cyclic group. These results are in accordance with the previous reports in anestrus cows $[2,6]$. However, the present first service conception rate in Ovsynch protocol is almost one-half of those $(50-58 \%)$ recorded by others in postpartum subestrus and/or anestrus buffaloes [3,15]. The first service conception rates found for mid-cycle $\mathrm{PGF}_{2} \alpha$ treated and $\mathrm{AI}+\mathrm{GnRH}$ injected repeat breeders were 40 and $30 \%$, respectively, and the overall conception rates of three cycles were 70 and $50 \%$, respectively (Figure-1), which corroborated well with the earlier reports in buffaloes [13] and crossbred cows [7]. Better results obtained with CIDR and Ovsynch protocols in anestrus buffaloes are attributed to continuous negative feedback effect of exogenous progesterone from the intra-vaginally inserted CIDR simulating CL function, and luteinization of some of the growing follicles and/or ovulation of dominant follicle and formation of CL under the influence of GnRH, simulating diestrus, followed by its sudden withdrawal on CIDR removal/PG injection causing rebound phenomenon and folliculogenesis, estrus and ovulation. Similarly, luteolysis and strengthening of timed ovulation and CL function with mid-cycle PG and GnRH at $\mathrm{AI}$ in repeat breeders enhance conception rate.

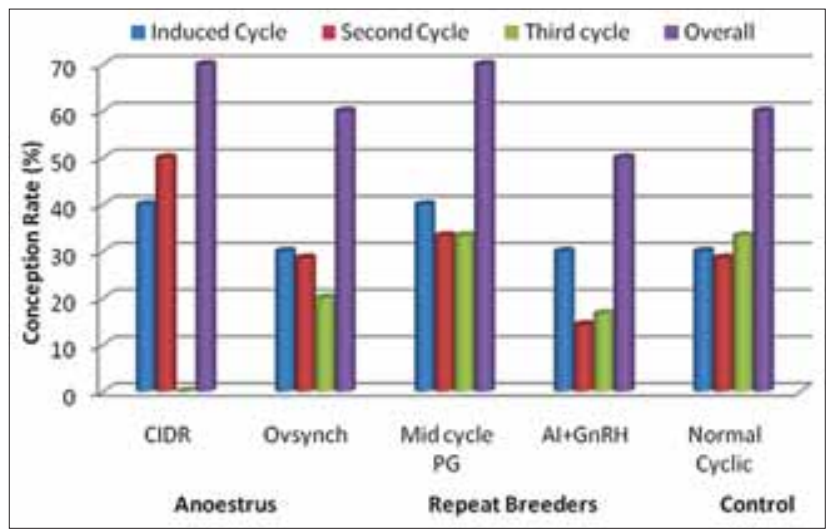

Figure-1: Conception rates at induced or first estrus in anestrus and repeat breeding buffaloes treated with different estrus synchronization protocols and in normal cyclic control group.

\section{Plasma progesterone profile}

The plasma progesterone $(\mathrm{ng} / \mathrm{ml})$ concentrations were low or near basal level on the day of initiation of treatment in both CIDR and Ovsynch protocols $(0.55 \pm 0.21$ and $0.56 \pm 0.23 \mathrm{ng} / \mathrm{ml})$, suggesting that the animals used in the experiment were in anestrus phase (Table-1). The levels increased highly significantly $(p<0.01)$ on day $7(4.76 \pm 0.57$ and $1.39 \pm 0.18 \mathrm{ng} / \mathrm{ml})$, i.e., just before CIDR removal and/or PG injection. The later resulted in sudden and significant drop in plasma progesterone level within $48-72 \mathrm{~h}$ with induction of estrus $(0.26 \pm 0.67 \mathrm{ng} / \mathrm{ml}$ in CIDR and $0.16 \pm 0.05 \mathrm{ng} / \mathrm{ml}$ in Ovsynch protocol). The pooled levels again rose significantly on day 21 post-AI in both the groups $(3.23 \pm 0.76$ and $2.00 \pm 0.86 \mathrm{ng} / \mathrm{ml})$ due to the establishment of pregnancy and maintenance of CL function in four and three buffaloes out of eight each in CIDR and Ovsynch group. Further, the variation between conceived and non-conceived groups in their plasma progesterone concentration was found to be non-significant on day 0,7 and 9/10 (AI), but on day 21 post-AI, the conceived buffaloes had significantly higher plasma progesterone concentration as compared to non-conceived ones in both the groups (Table-1). These findings on plasma progesterone profile with respect to the effect of CIDR and Ovsynch protocols closely corroborated with the earlier observations in cattle $[2,6,16]$ and buffaloes [3] using similar protocols. Raghorte et al. [17] also documented similar trend of plasma progesterone concentration in 12 postpartum buffaloes during Ovsynch protocol on different days and in pregnant and non-pregnant animals.

Significantly higher plasma $\mathrm{P}_{4}$ levels recorded on day 7 in CIDR group could be due to the continuous release of the exogenous progesterone from the intra-vaginally inserted progesterone impregnated device, while in the Ovsynch protocol this rise might be due to luteinization of some of the growing follicles and/or ovulation of dominant follicle and formation of CL under the influence of GnRH, simulating diestrus phase. Similarly, significantly higher plasma $\mathrm{P}_{4}$ recorded on day 21 post-AI in conceived buffaloes of both the treatment groups and even in normal cyclic control group was due to establishment of pregnancy and maintenance of CL function in them, while significantly low yet variable plasma $\mathrm{P}_{4}$ noted in non-conceived buffaloes could be due to their return to next estrus at varying intervals on account of probable irregular or long cycle length, early embryonic mortality or uncoordinated, unexplained hormonal changes in some of them.

Significantly higher mean plasma progesterone level $(3.81 \pm 0.67 \mathrm{ng} / \mathrm{ml})$ found on day of initiation of mid-cycle $\mathrm{PGF}_{2} \alpha$ treatment in repeat breeding buffaloes (Table-1) suggested that the buffaloes selected were really in mid-cycle or true luteal phase. The plasma $\mathrm{P}_{4}$ levels decreased significantly within $72 \mathrm{~h}$ of single PG injection with induced behavioral 
Table 1: Mean plasma progesterone concentrations $(\mathrm{ng} / \mathrm{ml})$ in anoestrus and repeat breeding buffaloes on different days of treatment and AI under various treatment protocols and in normal cyclic control group.

\begin{tabular}{|c|c|c|c|c|c|c|c|}
\hline \multirow{2}{*}{$\begin{array}{l}\text { Class of } \\
\text { animal }\end{array}$} & \multirow{2}{*}{$\begin{array}{l}\text { Treatment } \\
\text { protocol }\end{array}$} & \multirow[t]{2}{*}{ Status } & \multirow[t]{2}{*}{ Number } & \multicolumn{4}{|c|}{ Days from treatment/AI } \\
\hline & & & & D-0 & D-7 & D-9/10 (AI) & D-21 post-AI \\
\hline \multirow[t]{6}{*}{ Anestrus } & \multirow[t]{3}{*}{ CIDR } & Conceived & 4 & $0.62 \pm 0.37$ & $4.60 \pm 1.00$ & $0.23 \pm 0.13$ & $4.67 * \pm 0.56$ \\
\hline & & Non-conceived & 4 & $0.28 \pm 0.14$ & $4.90 \pm 0.70$ & $0.28 \pm 0.07$ & $1.78 \pm 0.97$ \\
\hline & & Overall & 8 & $0.55^{a} \pm 0.21$ & $4.76^{c} \pm 0.57$ & $0.26^{a} \pm 0.67$ & $3.23^{\mathrm{b}} \pm 0.76$ \\
\hline & \multirow[t]{3}{*}{ Ovsynch } & Conceived & 3 & $0.76 \pm 0.57$ & $1.60 \pm 0.50$ & $0.10 \pm 0.01$ & $4.87 * * \pm 0.48$ \\
\hline & & Non-conceived & 5 & $0.44 \pm 0.21$ & $1.25 \pm 0.05$ & $0.20 \pm 0.07$ & $0.28 \pm 0.12$ \\
\hline & & Overall & 8 & $0.56^{\mathrm{a}} \pm 0.23$ & $1.39^{\mathrm{b}} \pm 0.18$ & $0.16^{\mathrm{a}} \pm 0.05$ & $2.00^{\mathrm{b}} \pm 0.86$ \\
\hline \multirow[t]{6}{*}{ Repeat breeders } & \multirow[t]{3}{*}{ Mid-cycle PG } & Conceived & 4 & $4.02 \pm 0.67$ & & $0.26 \pm 0.88$ & $5.98 * \pm 0.82$ \\
\hline & & Non-conceived & 4 & $3.61 \pm 1.28$ & & $0.90 \pm 0.73$ & $2.10 \pm 0.92$ \\
\hline & & Overall & 8 & $3.81^{b} \pm 0.67$ & & $0.58^{a} \pm 0.36$ & $4.03^{b} \pm 0.93$ \\
\hline & \multirow[t]{3}{*}{$\mathrm{AI}+\mathrm{GnRH}$} & Conceived & 3 & & & $0.14 \pm 0.04$ & $6.60 \pm 0.95$ \\
\hline & & Non-conceived & 5 & & & $0.32 \pm 0.12$ & $3.09 \pm 1.56$ \\
\hline & & Overall & 8 & & & $0.25^{\mathrm{a}} \pm 0.81$ & $4.40^{\mathrm{b}} \pm 1.17$ \\
\hline \multirow[t]{3}{*}{ Normal cyclic } & \multirow[t]{3}{*}{ Control } & Conceived & 3 & & & $0.30 \pm 0.20$ & $5.45 * \pm 1.11$ \\
\hline & & Non-conceived & 5 & & & $0.46 \pm 0.27$ & $1.55 \pm 1.01$ \\
\hline & & Overall & 8 & & & $0.40^{\mathrm{a}} \pm 0.18$ & $3.01^{\mathrm{b}} \pm 1.00$ \\
\hline
\end{tabular}

$* p<0.05, * * p<0.01$, between conceived and non-conceived subgroups within the protocol/group. Means bearing uncommon superscripts within the row differ significantly $(p<0.05)$. D-0=Day of starting the treatment,

D-7=Administration of PG, D-9/10=Fixed time AI (Day 9 in CIDR; Day 10 in Ovsynch, Day 3 and 4 in mid-cycle PG),

$\mathrm{D}-21=$ Day 21 post-AI. AI=Artificial insemination, $\mathrm{PG}=$ Prostaglandin, $\mathrm{GnRH}=$ Gonadotropin-releasing hormone

estrus in $90 \%$ of buffaloes proving successful luteolysis. The mean plasma $\mathrm{P}_{4}$ level $(\mathrm{ng} / \mathrm{ml})$ on day 21 post-AI was significantly $(\mathrm{p}<0.05)$ higher in conceived than non-conceived buffaloes $(5.98 \pm 0.82$ vs. $2.10 \pm 0.92 \mathrm{ng} / \mathrm{ml})$. This indicated better ovulatory estrus and maintenance of luteal function with establishment of pregnancy in former group.

The mean plasma progesterone levels on day of AI and day 21 post-AI in repeat breeding buffaloes injected with GnRH at AI were $0.25 \pm 0.81$ and $4.40 \pm 1.17 \mathrm{ng} / \mathrm{ml}$, respectively. The results suggest that the animals were in true estrus with basal level of plasma progesterone when inseminated and simultaneously treated with GnRH. Further, the relatively higher plasma $\mathrm{P}_{4}$ noted on day 21 post-AI even in non-conceived group $(3.09 \pm 1.56 \mathrm{ng} / \mathrm{ml})$ indicated that these animals returned to estrus at varying and delayed interval. Two of the four non-conceived repeat breeding buffaloes had plasma $\mathrm{P}_{4}$ between 3 and $4 \mathrm{ng} / \mathrm{ml}$ on day 21 post-AI suggesting long cycle and/or EED later on (Table-1). Gustafsson et al. [18] opined that hormonal asynchrony starts before or early in estrus presumably leading to improper hormonal sequential changes responsible for the elevated embryonic loss during the first 3 weeks after AI in repeat breeding animals. The present findings corroborated well with those of Patel et al. [7] in repeat breeding cows using similar treatment protocols. Butani et al. [19] reported comparable serum progesterone values of $0.45 \pm 0.05$ and $0.36 \pm 0.08 \mathrm{ng} / \mathrm{ml}$ at the time of estrus in repeat breeding and normal cyclic buffaloes, respectively.

\section{Plasma total cholesterol}

The plasma total cholesterol profile did not reveal significant differences between days/periods of the treatment in any of the groups of anestrus and repeat breeding buffaloes and even in normal cyclic group, but the pooled values irrespective of periods were apparently or significantly $(\mathrm{p}<0.05)$ higher in non-conceived than conceived buffaloes of all the three groups. Similarly, the overall mean values of total cholesterol were significantly $(p<0.01)$ lower in all the treatment groups than in normal cyclic controls $(86.11 \pm 3.34$ $121.72 \pm 4.28$ vs. $138.04 \pm 11.98$ vs. $\mathrm{mg} / \mathrm{dl}$; Table-2). Similar results were observed by earlier workers in anestrus Gir and crossbred cows under CIDR and Ovsynch protocols [6,16], and in repeat breeding cows under mid-cycle PG and AI plus GnRH treatments [7]. Patel et al. [20] reported significantly lower serum cholesterol level in GnRH treated group of repeat breeding cows as compared to control group, and non-significantly lower values in conceived and non-conceived cows. Significantly $(\mathrm{p}<0.05)$ higher plasma total cholesterol concentrations observed in non-conceived than conceived cows consistently over the periods under study indirectly reflected its role in steroidegenesis, particularly progesterone synthesis in conceiving buffaloes. The higher level of cholesterol associated with estrogen synthesis resulting in the manifestation of heat in buffaloes has also been reported earlier [21]. Kapadiya and Siddiquee [22] documented significantly higher plasma cholesterol concentration on day of estrus as compared to day 12 of the estrous cycle in repeat breeding Mehsana buffaloes. Further, significant differences recorded between cyclic and anestrus/ repeat breeding buffaloes of different breeds $[19,23,24]$ to some extent corroborated well with the present findings of significantly higher plasma cholesterol in normal cyclic than the anestrus buffaloes.

\section{Plasma total protein}

Like cholesterol, the plasma total protein levels did not vary significantly between different days 
Table 2: Mean plasma total cholesterol concentrations $(\mathrm{mg} / \mathrm{dl})$ in anestrus and repeat breeding buffaloes conceiving and not conceiving following various treatment protocols and in normal control group.

\begin{tabular}{|c|c|c|c|c|c|}
\hline $\begin{array}{l}\text { Reproductive } \\
\text { status }\end{array}$ & $\begin{array}{l}\text { Treatment } \\
\text { protocol }\end{array}$ & Status & Number & $\begin{array}{c}\text { Total cholesterol } \\
(\mathrm{mg} / \mathrm{dl})\end{array}$ & $\begin{array}{c}\text { Total protein } \\
\text { (g/dl) }\end{array}$ \\
\hline \multirow[t]{6}{*}{ Anestrus } & CIDR & Conceived & 4 & $79.96 \pm 2.17$ & $8.14 * \pm 0.73$ \\
\hline & & Non-conceived & 4 & $92.27 * \pm 6.04$ & $7.69 \pm 0.59$ \\
\hline & & Overall & 8 & $86.11 \pm 3.34$ & $7.91 \pm 0.10$ \\
\hline & Ovsynch & Conceived & 3 & $109.44 \pm 4.15$ & $7.96 \pm 0.22$ \\
\hline & & Non-conceived & 5 & $129.08 * \pm 5.69$ & $8.10 \pm 0.15$ \\
\hline & & Overall & 8 & $121.72 \pm 4.28$ & $8.05 \pm 0.12$ \\
\hline \multirow[t]{6}{*}{ Repeat breeders } & Mid-cycle PG & Conceived & 4 & $101.49 \pm 10.99$ & $11.62 \pm 0.20$ \\
\hline & & Non-conceived & 4 & $106.69 \pm 9.86$ & $11.07 \pm 0.40$ \\
\hline & & Overall & 8 & $104.09 \pm 7.23$ & $11.34 \pm 0.23$ \\
\hline & $\mathrm{AI}+\mathrm{GnRH}$ & Conceived & 3 & $107.87 \pm 5.71$ & $8.05 \pm 0.20$ \\
\hline & & Non-conceived & 5 & $126.02 \pm 7.87$ & $8.01 \pm 0.18$ \\
\hline & & Overall & 8 & $119.21 \pm 5.70$ & $8.02 \pm 0.13$ \\
\hline \multirow[t]{3}{*}{ Normal cyclic } & Control & Conceived & 3 & $111.40 \pm 21.25$ & $7.61 \pm 0.11$ \\
\hline & & Non-conceived & 5 & $154.03 * \pm 6.42$ & $7.96 \pm 0.16$ \\
\hline & & Overall & 8 & $138.04 \pm 11.98$ & $7.82 \pm 0.11$ \\
\hline
\end{tabular}

$*_{p}<0.05$, between conceived and non-conceived subgroups within the protocol/group. AI. AI=Artificial insemination, $\mathrm{PG}=$ Prostaglandin, $\mathrm{GnRH}=$ Gonadotropin-releasing hormone

of sampling in anestrus, repeat breeding and normal cyclic buffaloes, except for Ovsynch wherein it was higher on the day of induced estrus/AI than other days. The total protein concentration was apparently or significantly higher in conceived than non-conceived buffaloes of CIDR, mid-cycle PG and AI + GnRH protocols, while, in Ovsynch protocol and normal cyclic control, the trend was inverse and insignificant. The plasma protein profile was higher in repeat breeders under mid-cycle PG protocol as compared to all other groups including normal cyclic control, which were at par (Table-2). These findings corroborated to the earlier observations with similar protocols in cows [6,16]. Gentile et al. [25] opined that serum protein level was not related with fertility in dairy cows, while Lodhi et al. [26] opined that the Murrah buffaloes having high level of total protein had good reproductive performance. Butani et al. [19] found significantly higher serum total protein concentrations in cycling as compared to repeat breeding buffaloes. Kapadiya and Siddiquee [22] recorded slightly higher plasma total protein value on day of estrus $(6.701 \pm 0.133 \mathrm{~g} / \mathrm{dl})$ as compared to day $12(6.368 \pm 0.318 \mathrm{~g} / \mathrm{dl})$ and day $24(6.321 \pm 0.090 \mathrm{~g} / \mathrm{dl})$ of estrous cycle in repeat breeding Mehsana buffaloes, which is in line with the present findings, but with lower values. The present insignificant variations observed in anestrus and normal cyclic buffaloes also corroborated well with the earlier reports in cattle and buffaloes [19,24,27].

\section{Conclusion}

The results showed that CIDR was better than Ovsynch protocol in inducing fertile oestrus in anestrus buffaloes while mid-cycle PG treatment was superior over $\mathrm{AI}+\mathrm{GnRH}$ in repeat breeder buffaloes. All these protocols influenced the plasma progesterone profile significantly but had no such effect on plasma cholesterol and protein levels. The values of total cholesterol were significantly higher and protein lower in normal cyclic when compared to problem breeders.

\section{Authors' Contributions}

AJD planned and designed the study. The experiment was conducted by KKS, AJD, KKH and KRP, while laboratory work was done by NPS and KKS. All authors participated in data analysis, draft and revision of the manuscript. All authors read and approved the final manuscript.

\section{Acknowledgments}

The authors are thankful to the Dean, Faculty of Veterinary Science for providing necessary laboratory facilities to carry out this research work and the Director of Research and Dean PG Studies, AAU, Anand for financial support.

\section{Competing Interests} interests.

The authors declare that they have no competing

\section{References}

1. Baruselli, P.S., Madureira, E.H., Visintin, J.A., Barnabe, V.H., Barnabe, R.C. and Amaral, R. (1999) Timed insemination using synchronization of ovulation in buffalo. Rev. Bras. Reprod. Anim., 23: 360-362.

2. Bhoraniya, H.L., Dhami, A.J., Naikoo, M., Parmar, B.C. and Sarvaiya, N.P. (2012) Effect of oestrus synchronization protocols on plasma progesterone profile and fertility in postpartum anoestrus Kankrej cows. Trop. Anim. Health Prod., 44(6): 1191-1197.

3. Naikoo, M., Patel, D.M., Sarvaiya, N.P. and Killedar, A. (2010) Estrus synchronization in postpartum anoestrus Mehsana buffaloes using different hormone protocols. Indian J. Field Vet., 6(2): 1-4.

4. Ravikumar, K., Asokan, S.A. and Veerapandian, C. (2007) Inclusion of CIDR in Ovsynch protocol to improve fertility in postpartum anestrus buffaloes. Tamil Nadu J. Vet. Anim. Sci., 3: 24-28.

5. Butani, M.G., Dhami, A.J., Kumar, R., Hirani, N.D., Ramani, V.P. and Patel, K.P. (2009) Influence of hormonal and antibiotic therapy on fertility and trace minerals profile 
in a repeat breeding buffaloes. Indian J. Field Vet., 3(3): 12-16.

6. Patel, K.R., Dhami, A.J., Hadiya, K.K., Savalia, K.K. and Sarvaiya, N.P. (2013) Effect of CIDR and Ovsynch protocols on estrus response, fertility and plasma progesterone and biochemical profile in true anoestrus crossbred cows. Indian J. Anim. Prod. Manage., 29(3-4): 50-58.

7. Patel, K.R., Dhami, A.J., Hadiya, K.K., Savalia, K.K., Killedar, A. and Patel, S.B. (2014) Effect of mid-cycle PGF $2 \alpha$ and GnRH at AI on conception rates, plasma progesterone and biochemical profile in repeat breeding crossbred cows. Indian J. Field Vet., 9(3): 5-11.

8. Kubasic, N.P., Hallauer, G.D. and Brodows, R.G. (1984) Evaluation of direct solid-phase RIA for progesterone, useful for monitoring luteal function. Clin. Chem., 30(2): 284-286.

9. Lakra, B.S., Luthra, R.A., Khar, S.K., Nanda, T. and Beniwal, B.S. (2003) Induction of cyclicity in anoestrus buffaloes during non-breeding season. Intas Polivet, 11(4): 162-164.

10. Singh, R.S., Saxena, A., Ghuman, S.P.S., Kumar, B., Singh, S. Verma, A.K., and Hussain, A. (2010) Effect of progesterone impregnated intravaginal sponges on induction of estrus and conception rate in buffalo heifers. Proceeding XXVI Annual Convention of ISSAR and International Symposium held at GBPUA \& T, Pantnagar, India, 10-12 Nov. p47.

11. Ingawale, M.V., Ingale, H.R. and Samad, A. (2007) Improvement of postpartum fertility with Ovsynch protocol in buffaloes. Proceeding XXIII Annual Convention of ISSAR and National Symposium, 7-9 Dec. QUAT, Bhubaneswar, India. p340.

12. Ali, R., Shukla, S.P. and Nema, S.P. (2012) Hormonal induction of ovarian cyclicity and conception rate in postpartum anoestrus buffaloes. Indian J. Field Vets., 7(4): 44-46.

13. Sathiamoorthy, T., Parthasarathy, R., and Kathirchelvan, M. (2007) Efficacy of PGF alpha, CIDR and Ovsynch treatment on oestrus induction and fertility in postpartum buffaloes. Indian. J. Anim. Reprod., 28(1): 8-11.

14. Khasatiya, C.T., Kavani, F.S., Dhami, A.J., Derashri, H.J., Panchal, M.T. and Desai, P.M. (2008) Studies on puerperal events and reproductive efficiency following hormone therapy at day 42 postpartum in Surti buffaloes. Int. J. Agri. Biol., 1: 132-137.

15. Pawshe, C.H., Ingawale, M.V., Deshmukh, S.G., Munde, V.K. and Pawshe, M.D. (2011) Estrus synchronization in bovine: Present status and future perspective. Lead Paper in Proceeding National Symposium and XXVII Annual Convention of ISSAR, 27-29 Sep. Mizoram, India, p78-82.

16. Ramakrishnan, A., Dhami, A.J., Killedar, A. and
Pande, A.M. (2012) Postpartum plasma progesterone and metabolic profile in pregnant and non-pregnant Gir cows following estrus synchronization. Indian J. Anim. Prod. Manage., 24(1-2): 40-44.

17. Raghorte, Y.M., Chinchkar, S.R., Sahatpure, S.K., Gawande, A.P., Gaikwad, S.M., Dhakate, M.S., Raut, J.D., Gote, S.G. and Verma, T. (2009) Progesterone concentration during Ovsynch protocol in buffalo heifers and postpartum buffaloes. Procceeding XXV Annual Convention of ISSAR and National Symposium held at Namakkal, Tamilnadu, India, 10-12 Dec. p43.

18. Gustafsson, H., Larson, K., Kindahl, H. and Madej, A. (1986) Sequential endocrine changes and behaviour during oestrus and metoestrus in repeat breeder and virgin heifers. Anim. Reprod. Sci., 10(4): 261-273.

19. Butani, M.G., Dhami, A.J. and Kumar, S. (2011) Comparative blood profile of progesterone, metabolites and minerals in anoestrus, suboestrus, repeat breeding and normal cyclic buffaloes. Indian J. Field Vet., 7(2): 20-24.

20. Patel, J.A., Dhami, A.J., Kavani, F.S. and Jani, R.G. (2005) Effect of hormonal therapies at breeding on conception rates and plasma biochemical profiles in repeat breeding HF cows. XXI Annual Convention of ISSAR and National Symposium. Nov, 23-25. Jammu, India. p127.

21. Singh, I.D., Sinha, S.N., Singh, B. and Verma, S.B. (1983) Effect of some oestrus inducing drugs on total serum cholesterol level in cattle. Indian J. Anim. Reprod. 22(2): 157-160.

22. Kapadiya, F.M. and Siddiquee, G.M. (2013) Blood biochemical profile in repeat breeding Mehsana buffaloes. Indian J. Field Vet., 8(3): 32-35.

23. Bansraj, P., Shukla, S.P., Nema, S.P. and Misrrauliya, K.S. (2007) Therapeutic studies in anoestrus buffaloes. XXIII Annual Convention of ISSAR and National Symposium, 7-9 December, QUAT, Bhubaneswar, Orissa, India.

24. Akhtar, M.S., Farooq, A.A. and Mushtaq, M. (2010) Biochemical and hormonal profile in anoestrus Nili-Ravi buffaloes. Indian Vet. J., 87: 603-604.

25. Gentile, G., Moretti, M., Gaiani, R. and Giordani, L. (1978) Correlation between some biochemical constituents and low fertility in Moderice province. Clin. Vet., 101:17-24.

26. Lodhi, L.A., Qureshi, Z.I., Khan, A. and Hayat, S. (1998) Comparative study of blood glucose, total proteins, calcium and phosphorus in cycling, non-cycling, repeat breeding and endometritic buffaloes. Pak, J. Biol. Sci., 1(2): 66-68.

27. Pravesh, K. Singh, M. and Vasishta, N.K. (2007) Studies on the effect of progesterone supplementation on conception rate following artificial insemination in normal cows. Proceeding. XXIII Annual Convention of ISSAR and National Symposium, 7-9 December. QUAT, Bhubaneswar, Orissa, India.

\section{$* * * * * * * *$}

